\title{
Teaching English Pragmatic Features in EFL Context: A Focus on Request Speech Acts
}

\author{
Marzieh Saadatmandi \\ ELT Graduate Department, Islamic Azad University of Karaj Branch, Karaj, Iran \\ Shahram Modarres Khiabani \\ Department of English Language Translation, Islamic Azad University of Karaj Branch, Karaj, Iran
}

\author{
Natasha Pourdana \\ ELT Graduate Department, Islamic Azad University of Karaj Branch, Karaj, Iran
}

\begin{abstract}
This study attempted to explore the possible impacts of teaching English pragmatic features to Iranian high school students' use of request speech acts. To this end, a sample of Iranian female high school students $(n=50)$ between 12 to 18 years range of age participated in the study. The students with the same level of proficiency were assigned into two experimental and control groups. The data were collected by administering Multiple-Choice Discourse Completion Test (MDCT) as both the pre and the post-tests. The pragmatic features were selected from the high school English textbooks and the excerpts taken from the Top Notch series $(2 \mathrm{~A}, 3 \mathrm{~A}, 2 \mathrm{~B})$. With the focus on request speech acts, the control group received conventional instructions whereas the experimental group was exposed to the researchers' request speech act interventions. After statistical analysis of the findings, the data revealed that teaching pragmatic features has significant impact on the Iranian high school students' performance on request speech acts. Besides, the overall responses by the experimental group showed that indirect request speech acts were more widely used than direct request speech acts as the sign of social and cultural politeness.
\end{abstract}

Index Terms - discourse completion test, direct/indirect request, politeness, pragmatics, speech act

\section{INTRODUCTION}

Pragmatics is defined as a branch in language acquisition and one of the main components of organizational knowledge of language that has become one of the most critical concerns of linguist scholars (Karthik, 2013, p. 1). In a narrow linguistic view, "pragmatics studies the factors that govern our choices of language in social interaction and the effects of those choices on others" (Crystal, 2008, p. 379). Moreover, pragmatics deals only with those aspects of context which are encoded within the structures of a language user's pragmatic competence. More especially, pragmatics is known as the interdisciplinary fields of linguistics, sociology and psychology and so on. Hence, Verschueren points out that it is a "general cognitive, social, and cultural perspective on linguistic phenomena in relation to their usage in forms of behavior" (as cited in Culpeper \& Haugh, 2014, p. 7). In pragmatics, context may be defined as the set of suppositions which have critical effects on the production, and interpretation of communicative acts.

Language is the human-specific tool to transmit messages, emotions, and ideas and even to develop cross-lingual communication. Thus, language learners learn a new language by starting from the language they already know wherein learning this new language is usually influenced by the features of the first language. To communicate appropriately in a foreign language context, the language learners need to identify the pragmatic or context-bound features through some meaningful activities and pragmatic awareness-raising tasks (Safont Jordà, 2004, p. 25), so do the foreign language teachers consider the possibility of transferring pragmatic interlanguage features (Žegarac \& Pennington, 2008, p. 147).

Hereupon, in the last few decades the studies on fostering pragmatic competence of EFL learners have attracted lots of attention. Many studies were conducted on comparing the use of speech acts between native and non-native language speakers. Research supports the fact that EFL learners' competence for speech acts is mostly different from the native English speakers. Nevertheless, one of the ignored issues in interlanguage pragmatics research is the developing pragmatics knowledge of school students learning English as EFL and its effects on their success in speech acts. The belief is that there is a close link between the knowledge of pragmatics and successful communication by language learners. Especially in the polite and formal interactions between EFL learners, indirect speech acts are the confident means to save face and to show respect, particularly in Asian cultures when it comes to making requests (Khaliba \& Tayehb, 2014, p. 54).

In Iranian EFL context, the English teachers have complaints of the high school students' inappropriate declaring requests, the ambiguity, and the low level of politeness and directness (Safavi \& Zamanian, 2014; Zaferanieh \& Hosseini-Maasoum, 2015). By the same token, the current researchers aimed to investigate the effects of teaching English pragmatic features on Iranian high school students' performance of In/Direct speech acts requests. 


\section{REVIEW OF THE RELATED LITERATURE}

Pragmatics is a favorite term which is widely used in the EFL/ESL studies. It was a popular field of study in the late sixties and early seventies. As a branch of applied linguistics, pragmatics is concerned with language use and the situated meaning of utterances. In other words, it is the study of context dependent aspects of meaning which are systematically abstracted away from in the construction of content or logical form (Horn \& Ward, 2006). It is one of the keys to effective communication in a second language (Taguchi, 2009). In other words, it is all about communicating appropriately in a certain context.

Murray (2010) defines the pragmatic competence as an "understanding of the relationship between form and context that enables us, accurately and appropriately, to express or interpret intended meaning in terms of speech acts" (p. 293). According to Austin (1962), when language users express themselves, they may produce utterances with propositional contents which can be true or false in the real world. In other words, we are constantly doing things with words (as cited in Kilıçkaya, 2010, p. 187). Accordingly, a speaker produces three acts during the uttering a performative speech act: locutionary which is the speech itself or what is actually said (e.g. "what time do you call this?"). Illocutionary which is the force or intention produced in the said words (e.g. "an apology or explanation for someone being late"); and perlocutionary act which is the effect the said words have on the intended hearer (e.g. "Speaker is apologizing or explaining") (Suhirman, 2016, p. 22).

Although, Austin (1962) claims that "what we have to study is not the sentence but the issuing of an utterance in a speech situation" which reveals the speech acts that may be produced indirectly (as cited in Cline, 2002, p. 27), but his taxonomy lacked the sound representation of the communicative functions and affective factors that influence the speech acts. Speech act theorists focused on the force of speech acts to infer whether they were direct speech acts (directly marked) or indirect (indirectly marked). Hereupon, theories recommend the illocutionary force indicating devices as the appropriate way to recognize whether the speech act is directly marked or not (Trosborg, 1995; Green, 2016).

The use of an Illocutionary Force Indicating Device (IFID) is usually represented by a direct performative verb; also the speaker can signal the type of illocutionary act being performed on the outset of the utterance with performative verbs. For instance, a direct speech act is represented as a simple link between the words' illocutionary force and their perlocutionary effect on the hearer. Therefore, in order to reach the speaker's intended meaning, the hearer simply attends to the message with no inference.

Culpeper and Haugh (2014, p. 168) stated that the stress carried on the utterances which contain IFIDs might be closely dependent on and identifiable according to the context. For example, in "I promise I'll withhold your pocket money." it is not a promise rather a threat. This mismatch between the form of the utterance and its function is imposed by its illocutionary force, intonation and inference needs; hence there is a direct reference to what is an indirect speech act. As a result, the speaker can exploit the indirect speech act to communicate or say something with additional meaning which needs to be inferred by the hearer.

In the field of interlanguage pragmatics, Vásquez and Sharpless (2009) highlighted the importance of teaching pragmatics to EFL learners. Accordingly, pragmatic errors are more important than grammatical mistakes, hence the developing pragmatic competence takes a much longer time and efforts than linguistic competence. Moreover, a simple exposure to second language input can rarely provide adequate comprehensible pragmatic input to the learners. On the same vein, Furkó and Monós (2013) reminded that despite ample evidence to the difficulties that acquiring pragmatic competence relative to linguistic competence might expose the language learners, they are still teachable. In addition, they undelined the importance of "ample comprehensive input" and the relevance of noticing as only the starting point of cognitive processes to second language acquisition in any EFL environment" (p. 137). On the contrary, Doughty (2001) believed that learning of pragmatics involves a constant noticing, practicing and storing the input in long-term memory. Moreover, problems in performing suitable request speech act in socio-pragmatically ways might be the major reason for EFL learners' failure in appropriate pragmatic performance (Uso-Juan, 2010, p. 237). Hereupon, Ariana Ahmadi Shirazi, and Mousavi Nadoushani's (2017) noticing hypothesis emphasizes that pragmatic features must be so executed in EFL curricula that they consist of authentic input of different situations of target language use. Consequently, awareness to the social norms of the learners' culture and society is essential for material developers (Alemi \& Khanlarzadeh, 2017).

\section{A. Indirect Speech Acts}

In English, there are three major illocutionary forces or indirect speech acts associated with three basic sentence structures: (i) Declarative: assertion (e.g. That plant is green.); (ii) Interrogative: question/enquire (e.g. Do I have to water the plant?); (iii) Imperative: command/ordering (e.g. Water the plant, please!) (Culpeper \& Haugh, 2014, pp. 168-171). Considering the above examples, it can be observed that a particular speech act may be performed with different forms, so if there is between a speech act and its form, it is a direct speech act. In other words, direct speech acts are the utterances which the propositional content of the utterance is consistent with the speaker's intent (Achiba, 2003 , p. 7). On the contrary, if such correspondence does not exist, the speech act is indirect wherein the speakers' intentionality plays a critical role (Şanal, 2016). 
Searle (1979) asserted that there are "cases in which one illocutionary act is performed indirectly by means of performing another" (p. 30). Although, he revised his notion as with indirect speech acts, the interactants communicate with more than the speakers what they actually say. They usually have to rely on mutual and shared background knowledge and on each other's inferential and rational abilities. Indirect speech acts can also be considered as an appropriate means to create socially polite statements, commands, and requests (Lempert, 2012, p. 182) and as an inspiration to people's indirectness (Brown \& Levinson, 2009; Blum-Kulka, House, \& Kasper, 2010; Leech, 2013).

\section{B. Request Speech Acts}

Requesting is an essential speech act frequently used in social interactions. According to Alcón Soler and Safont Jordà (2008), request is performed by a speaker in order to push the hearer to do an action that "coincides with the speaker's goal" (p. 168). On one hand, requests as the first part of linguistic actions within adjacency pair sequences is a Face Threatening Act (FTA) because they threaten hearer's negative face. On the other hand, based on Searle's taxonomy of speech acts, requesting is an illocutionary act since it is dependent on the speaker's "directives" (as cited in Björgvinsson, 2011, p. 15). That later is called "impositives", too in order to avoid confusion in using the term "directive" in association with direct and indirect illocutions (Janochová, 2013, p. 34). Accordingly, Trosborg (1995) proposed that, the performance of requests could be softened by increasing the degree of politeness since the speaker's aim is to obtain non/verbal services. This politeness can be achieved by the use of linguistic indirectness on the part of the speaker. Trosborg (1995) developed the taxonomy of request strategies in which categories of requests are graded from direct to indirect. This taxonomy is based on previous research conducted by Austin (1962-1975), and Searle (1969-1976), but reformulated by Blum-Kulka and Olshtain (1984-1989), Brown and Levinson (1978-1988), and UsóJuan (2010). Trosborg (1995) classified requests into direct, conventionally indirect (hearer-based), conventionally indirect (speaker-based), and indirect.

In direct request, the intention of the speaker is explicitly revealed by its propositional content that can be recognized directly from its sentence structures such as imperatives or requesting verb phrases (e.g. Lend me your car., or Our car, please.). In conventionally indirect (hearer-based) speech acts, the speaker asks directly the hearer to obtain some services or benefit in which the requests are usually stated with the modal verbs so the requests are realized by questioning the speaker's ability, willingness or possibility (e.g. May I go to your house tomorrow? or Would you mind cleaning up the house?).

As it can be seen in the examples above, the speaker increases the level of politeness towards the hearer, since this type of request relies on the hearer's choice whether to accept the request. While in conventionally indirect (speakerbased) request, the speaker expresses his/her own volition without asking the hearer for permission or acceptance, so the requests are considered as less polite than hearer-based (e.g. I want/need to borrow your car.) Consequently, applying strategies of polite requests or avoiding face threatening acts are vital to successful communication in the real world.

The researchers developed a classification for direct requests strategies (Salmani Nodoushan, 2008; Blum-Kalka, et al., 2010; Salmani Nodoushan \& Allami, 2011; Xiaoning, 2017). This classification includes three dimensions of (i) internal and external modification (ii) directness level of the head act and (iii) the core request. While the internal modification is applied to soften and intensify the force of the request, the external modification is used either for mitigating moves or aggravating moves (Xiaoning, 2017, pp. 3-5). The head act is the core part of a request sequence which verbalizes the request.

Several empirical studies with cross-cultural perspectives have been conducted on the request speech acts. HalupkaResetar (2015) investigated two characteristics of request speech acts production. She stated that EFL learners' rate of requests is low in terms of internal and external modification and frequency of utilization. Halupka-Resetar (2015) has noted that the EFL learners' request production is due to pedagogical instruction which is significantly in a lower level than linguistic development. Accordingly, Cunningham (2017) has analyzed the requests production of L1/L2 speakers of German in synchronous computer-mediated communication (SCMC). He concluded that L1 speakers use more internal modification than the L2 speakers while both do not show a significant difference in their use of external modification (p. 92). On the contrary, Jaliliafar (2009) investigated the realization of request strategies utilized by EFL learners and native speakers of English. He concluded that the EFL learners at advanced level of language proficiency overused the indirect request strategies relative to the excessive use of direct request strategies by less proficient EFL learners.

\section{METHOD}

\section{A. Participants}

To achieve the aims of this research, 50 Iranian high school students at the pre-intermediate level of English language proficiency were randomly selected from three high schools in Tehran on a voluntary basis. They were all female students with the age range of 12 to 18 years who attended the twenty-one hours of the school summer semester. They were exposed to the selected units from Top Notch series (Saslow \& Ascher, 2015) and High School English textbooks (I, II, III) (Alavi Moghaddam, et al., 2015; Birjandi, Norowzi, \& Mahmoudi, 2015). This was a quasi-experimental research with a pre-test, an intervention period, and a post-test. The selected subjects were divided into one experimental and one control groups. 


\section{B. Instruments and Materials}

The Multiple-Choice Discourse Completion Test (MDCT):

In line with the purpose of current research, two versions of multiple-choice discourse completion test (MDCT) were administered twice to compare the participants' perception of the request speech acts: one prepared by Rezaei and Birjandi (2010) as the pre-test, and one by Soleimani and Birjandi (2013) as the post-test. The internal reliability indices of $(\alpha=0.80)$ and $(\alpha=0.78)$ was estimated using Cronbach's Alpha formula for the pre- and post-tests, respectively.

Material:

This study focused on the "making polite requests, making choices, providing description of objects, expressing specific personal needs, and requiring assistance" as the main features of pragmatic competence (Goberis, et al., 2012, pp. 302-303). The experimental group in this study received formal instructions after a brief introduction to the concept of English pragmatic features while the control group received conventional instructions to their English textbook.

Initially, the participants were equally and randomly assigned into two groups of experimental and control. In order to investigate the participants' pragmatic knowledge of request speech acts in English classrooms, Rezaei and Birjandi's (2010) multiple-choice discourse completion test (MDCT) was employed as the pre-test. Later, an explicit-deductive set of instructions, following the "presentation, recognition and production" (Usó-Juan, 2007, p. 238) model of teaching pragmatic features, was conducted with the experimental group. Awareness to request speech acts was raised with identification tasks to assess the participants. Ultimately, as the post-intervention test, the Soleimani and Birjandi's (2013) multiple-choice discourse completion test (MDCT) was employed as the post-test to assess the participants' achievement of the request speech acts in English.

\section{RESULTS AND DISCUSSION}

In order to tabulate the participants' scores on pre- and post-tests, statistical analysis was conducted and the results were summarized by Statistical Package for Social Sciences (SPSS) $20_{\text {th }}$ edition.

TABLE 1

DESCRIPTIVE STATISTICS FOR PRE-TEST AND POST-TEST SCORES

\begin{tabular}{|l|l|l|l|l|l|l|l|l|l|}
\hline \multirow{2}{*}{ Groups } & Min & Max & Mean & Std. Deviation & Skewness & \multicolumn{2}{l|}{ Kurtosis } \\
\cline { 3 - 10 } & & Statistic & Statistic & Statistic & Statistic & Statistic & Std. Error & Statistic & Std. Error \\
\hline \multirow{2}{*}{ Pre-test } & Experimental & 8.00 & 17.00 & 12.56 & 2.53 & -.34 & .46 & -.84 & .90 \\
& Control & 8.00 & 17.00 & 12.50 & 2.48 & .03 & .46 & -.93 & .90 \\
\hline \multirow{2}{*}{ Post-test } & Experimental & 9.00 & 16.00 & 13.56 & 2.06 & -.95 & .46 & -.16 & .90 \\
& Control & 7.00 & 16.00 & 12.44 & 2.32 & -.11 & .46 & -.77 & .90 \\
\hline
\end{tabular}

As Table 1 shows, the experimental group shows considerable improvement after receiving the request speech act intervention. It also shows a lower standard deviation since the experiment started. In other words, it shows that instructions to request speech act has caused a homogeneous and steady improvement among the participants in this study. Furthermore, to observe the homogeneity of variance and normality of scores distribution on pre- and post-tests a Levene's test was administered.

TABLE 2

LEVENE'S TEST OF HOMOGENEITY OF VARIANCES

\begin{tabular}{|l|l|l|l|l|}
\hline & Levene's Statistic & df1 & df2 & Sig. \\
\hline Pre-tests & .005 & 1 & 48 & .94 \\
Post-tests & .78 & 1 & 48 & .38 \\
\hline
\end{tabular}

As it can be seen in Table 2, the variance of both groups' scores was insignificant across the pre- and post-tests $(\alpha=.98>.05, \alpha=.38>.05$, respectively. To testify the formulated research null hypothesis, the inferential statistics was run with the parametric test of ANOVA.

TABLE 3

ANOVA TEST ON THE EFFECT OF TEACHING PRAGMATIC ON IN/DIRECT REQUESTS

\begin{tabular}{|c|c|c|c|c|c|c|}
\hline & & Sum of Squares & $\mathrm{df}$ & Mean Square & $\mathrm{F}$ & Sig. \\
\hline \multirow[b]{2}{*}{ Pre-tests } & Between Groups & .00 & 1 & .00 & .000 & 1.00 \\
\hline & Within Groups & 302.32 & 48 & 6.29 & & \\
\hline \multirow{3}{*}{ Post-tests } & Between Groups & 56.18 & 1 & 56.18 & 11.60 & .001 \\
\hline & Within Groups & 232.32 & 48 & 4.84 & & \\
\hline & Total & 288.50 & 49 & & & \\
\hline
\end{tabular}

The indices of $\mathrm{F}$ in Table 3 show that, for the scores of both groups on the pre-test, the $\mathrm{F}=0$, insignificant at $\mathrm{p}$ value $=1.00>.05$. In other words, the experimental and control groups did not show any difference in their performance on the pre-test. On the other hand, the measure of $\mathrm{F}$ for both experimental and control groups' scores on the post-test is $\mathrm{F}=11.60$, significant at $\mathrm{p}$-value $=.001<.05$. This proves the different performance of the experimental group from the control group on the post-test after receiving intervention in this study. Accordingly, the researchers concluded that 
intervention in terms of request speech acts had observable impacts on Iranian EFL learners. To measure the size of this impact and ensure its magnitude, the Eta Squared was calculated.

TABLE 4

EFFECT SIZE FOR THE POST-TEST SCORES

\begin{tabular}{|l|l|l|}
\hline & Eta & Eta Squared \\
\hline Posttests * Groups & .44 & .190 \\
\hline
\end{tabular}

As it can be seen in Table 4, the measure of $\mathrm{Eta}^{2}=.190$ according to Cohn (1988)is a very large effect size which is interpreted as the effectiveness of the intervention to make a considerable improvement in the experimental group's performance on the post-test. Hereby, the researchers could safely reject their null hypothesis in this study.

The researchers' main concern in this study was to reexamine the effectiveness of direct exposure to the request speech acts on the Iranian high school students' pragmatic competence. The overall responses by the experimental group showed that conventionally indirect requests have been widely preferred over direct requests. To compare the classes of request speech acts used by the students, both groups preferred the indirect speech acts on the pre-test for $62.8 \%$ of the times, while $84.75 \%$ of the experimental group preferred direct speech acts and $71.5 \%$ of the control group used indirect speech acts address on the post-test. As a result, after exposing to both classes of request speech acts, the experimental group changed their preference for more direct request speech acts.

For instance, as a new experience, the participants practiced to require their teacher to write them a recommendation letter, by asking "Write me a recommendation letter, please." as a direct request strategy, while the frequent use of modal verbs such as could in "Could you write a recommendation letter for me?" as an indirect and polite strategy was commonly used.

Iranian high school students, however, mostly prefer to use the indirect requests strategies to minimize the risk of losing their face on formal occasions. Consequently, some participants regressed to "Could you please" to address equal-status classmates to ensure receiving positive responses that overshadowed their choice for direct requests. This phenomenon seems to be in accordance with Fukushima who found that Japanese EFL learners switched to direct request strategies in both formal and informal occasions (as cited in Konakahara, 2011, p. 257).

It should be noted that cultural dimension of pragmatic knowledge has a prominent role in language learners' communication practice. As (Ogiemann, 2009) asserted, "the dimensions of individualism and power distance have proved most influential in studies linking culture with verbal behavior" (p. 25). Analysis of the responses in this study has shown that the Iranian language learners frequently use the indirect request speech acts could as a negative politeness signal for the unequal status hearers followed by please; while they prefer I want you as a positive politeness signal for statues equals. Therefore, L2 language learners' sociological variables like power, social distance, and rank of imposition are reflected in terms of polite language to preserve their interlocutors' face and distance.

\section{CONCLUSION}

The objective in this research was to illuminate the necessity and importance of developing pragmatic knowledge hand in hand with the language competence in L2 learners. The findings in the current research not only emphasize the improvement of pragmatic knowledge in L2 learners, but also promote different contextual variations inside language classrooms as a requisite for successful communications. Therefore, some direct and indirect request forms were selected with a communicative purpose in the target language to be introduced and practiced by high school students in their English courses. It was concluded that instructional input to request speech acts had a positive impact so that the experimental group reached a higher rate and appropriateness in using direct/indirect request strategies. However, the results suggested that Iranian high school students would show a high degree of variance in their degree of pragmatic awareness after receiving instructions.

The effectiveness of teaching different classes of speech acts in English language classrooms is undisputable in terms of an optimal instructional approach for pragmatic development in an EFL environment. The language students require having access to comprehensible and pragmatic input. Their attention should not only become confined to syntactic and lexical aspects of the language. Since English textbooks are usually packed with isolate, simple and de-contextualized instances of language; the pragmatic components of the language cannot reach its optimal level to be learnt (Usó-Juan, 2007; Salazar Campillo, 2007). Research, therefore, should budget to preparing texts and tasks to pump the pragmatic competence and communicative aspects.

\section{REFERENCES}

[1] Achiba, M. (2003). Learning to request in a second language a study of child interlanguage pragmatics. Great Britain: Cromwell Press Ltd.

[2] Alavi Moghadam, S. B., Kheirabadi, R., Forouzandeh Shahraki, E., Khadir Sharbian, Sh., \& Nikopour, J. (2015). Prospect. Tehran: Center for authoring textbooks.

[3] Alcón Soler, E., \& Safont Jordà, M. P. (2008). Intercultural language use and language learning. Netherlands: Springer.

[4] Alemi, M. \& Khanlarzadeh, N. (2017). Native and non-native teachers' pragmatic criteria for rating request speech act: The case of American and Iranian EFL teachers. Applied Research on English Language 6.1, 67-84. 
[5] Ariana, N., AhmadiShirazi, M., \& Mousavi Nadoushani, S. M. (2017). An explicit/implicit lead to producing requests: Eliciting learners' awareness or soliciting metapragmatic knowledge. IJALE 6.1, 115-127. doi: 10.7575/aiac.ijalel.v.6n.1p.115.

[6] Birjandi, P., Norowzi, M., \& Mahmoudi, Gh. (2015). English book. Tehran: Center for authoring textbooks.

[7] Björgvinsson, L. Á. (2011). Speech act theory: A critical overview. Bachelor thesis, University of Iceland.

[8] Blum-Kulka, S., House, J., \& Kasper, G. (2010). Cross-cultural pragmatics: Requests and apologies. In E. V. Shcherbakova, appropriateness in requests: Perspectives of Russian EFL learners. Master thesis, Lowa State University.

[9] Brown, P., \& Levinson, S. C. (2009). Politeness: Some universals in language usage. In E. Ogiermann, Politeness and indirectness across cultures: A comparison of English, German, Polish and Russian requests. Journal of Politeness Research, 5, 189-216. dio: 10.1515/JPLR.2009.011.

[10] Cline, A. R. (2002). Understand and act classical rhetoric, speech acts, and the teaching of critical democratic participation. $\mathrm{Ph}$.D. dissertation, University of Missouri-Kansas City.

[11] Cohen, J. (1988). Statistical power analysis for the behavioral sciences (2nd ed.). United States: Lawrence Erlbaum Associates.

[12] Crystal, D. (2008). A dictionary of linguistics and phonetics ( $4^{\text {th }}$ ed.). Cambridge: Blackwell.

[13] Culpeper, J., \& Haugh, M. (2014). Pragmatics and the English language, perspectives on the English language. Basingstoke, United Kingdom: Palgrave Macmillan.

[14] Cunningham, D. J. (2017). Methodological innovation for the study of request production in telecollaboration. Language Learning \& Technology 21.1, 75-98.

[15] Doughty, C. (2001). Cognitive underpinnings of focus on form. In P. Robinson (eds.), Cognition and second language instruction. UK: Cambridge University Press, 206-257

[16] Furkó, B. P., \& Mónos, K. (2013). The teachability of communicative competence and the acquisition of pragmatic markers: A case study of some widely-used business English coursebooks. Argumentum 9, 132-148.

[17] Goberis, D., Beams, D., Dalpes, M., Abrisch, A., Baca, R., \& Itano, C. Y. (2012). The missing link in language development of deaf and hard of hearing children: Pragmatic Language development. Seminars in Speech and Language 30.4, $297-309$. doi:http://dx.doi.org/10.1055/s-0032-1326916.

[18] Green, M. (2016). Speech acts. Oxford Research Encyclopedia of Linguistics, 1-15. doi: http://dx.doi.org/10.1093/obo/9780195396577-0300.

[19] Halupka-Rešetar, S. (2015). Request modification in the pragmatic production of intermediate ESP learners. E.S.P. Today 2.1, 29-47.

[20] Horn, L., \& Ward, G. (2006). The handbook of pragmatics. United States: Wiley-Blackwell.

[21] Jalilifar, A. (2009). Request strategies: Cross-sectional study of Iranian EFL learners and Australian native speakers. English Language Teaching, 2.1, 46-61.

[22] Janochová, L. (2013). Indirect requests in politeness theories. Bachelor's diploma, the Masaryk University.

[23] Karthik, D. S. (2013). Pragmatics and language communication. The Criterion 4.3, 1-9.

[24] Kilıçkaya, F. (2010). The pragmatic knowledge of Turkish EFL students in using certain request strategies. Gaziantep Üniversitesi Sosyal Bilimler Dergisi 9.1, 185-201.

[25] Konakahara, M. (2011). Requests in Japanese learners' English in comparison with British English and Japanese. Bulletin of the Graduate School of Education of Waseda University 18.2, 245-260.

[26] Leech, G. (2013). Principles of pragmatics. In A. Šubertová, Aspects of politeness in a classroom of English as a second language. Diploma thesis, Charles University in Prague.

[27] Lempert, M. (2012). Indirectness. In C. B. Paulston; S. F. Kiesling, \& E. S. Rangel, the handbook of intercultural discourse and communication. United States: Wiley-Blackwell, 180-204.

[28] Mohd. Khaliba, F., \& Tayehb, A. (2014). Indirectness in English requests among Malay university students. Social and Behavioral Sciences 134, 44-52. doi: 10.1016/j.sbspro.2014.04.223.

[29] Murray, N. (2010). Pragmatics, awareness raising, and the cooperative principle. ELT Journal 64.3, 293-301. doi: https://doi.org/10.1093/elt/ccp056.

[30] Ogiemann, E. (2009). On Apologizing in negative and positive politeness cultures. Amsterdam Philadelphia: John Benjamins Publishing Company.

[31] Rezaei, S., \& Birjandi, P. (2010). Developing a multiple-choice discourse completion test of interlanguage pragmatics for Iranian EFL learners. ILI Language Teaching Journal 6.1, 2, 43-58.

[32] Safavi, M., \& Zamanian, M. (2014). Investigating the effect of gender, age, education, and status on distribution of politeness strategies in Persian requestive speech acts. IJLLALW 7.2, 127-135.

[33] Safont Jordà, M. P. (2004). An analysis on EAP learners' pragmatic production: a focus on request forms. IBÉRICA 8, 23-39.

[34] Salazar Campillo, P. (2007). Examining mitigation on requests: A focus on transcripts in ELT course books. In E. Alcón, \& M. P. Safont Jordà (eds), Intercultural language use and language learning. The Netherlands: Springer, 207-222.

[35] Salmani Nodoushan, M. A. (2008). Persian requests: Redress of face through indirectness. International Journal of Language Studies 2.3, 257-280

[36] Salmani Nodoushan, M. A., \& Allami. H. (2011). Supportive discourse moves in Persian requests. International Journal of Language Studies 5.2, 65-94.

[37] Şanal, M. (2016). Conceptual socialization in EFL contexts: A case study on Turkish EFL learners' request speech acts realization. Master thesis, the Bilkent University.

[38] Saslow, J., \& Ashcher, A. (2015). Top notch ( $3^{\text {rd }}$ ed.). United Stated: Pearson Education.

[39] Searle, J. (1979). Expression and meaning. New York: Cambridge University Press.

[40] Soleimani, M. M., \& Birjandi, P. (2013). Assessing language learners' knowledge of speech acts: A test validation study. ILT 2.1, 1-26.

[41] Su, H. (2017). Local grammars of speech acts: An exploratory study. Journal of Pragmatics 11, 72-83. doi: 10.1016/j.pragma.2017.02.008.

[42] Suhirman, L. (2016). Speech acts in psycholinguistics class setting in postgraduate program. IJOLTL 1.1, 19-36. 
[43] Taguchi, N. (2009). Pragmatic competence. New York: Mouton de Gruyter.

[44] Tayebipour, F. \& Tajeddin, Z. (2017). Dynamic assessment embedded into pragmatic instruction: The impact of fine-tuned scaffolding on EFL learners' speech act production strategies. In C. Coobme, P. Davidson, A. Gebril, \& S. Hidri, Language assessment in the middle east and north Africa: Theory, practice and future trends. UAE: TESOL Arabia, 192-211.

[45] Trosborg, A. (1995). Interlanguage pragmatics: Requests, complaints and apologies. Berlin/ New York: Mouton de Gruyter.

[46] Usó-Juan, E. (2007). The presentation and practice of the communicative act of requesting in textbooks: Focusing on modifiers. In E. Alcón, \& M. P. Safont Jordà, Intercultural language use and language learning. The Netherlands: Springer, 223-244.

[47] Usó-Juan, E. (2010). Requests: A sociopragmatic approach. In A. Martínez-Flor, \& E. Usó-Juan, Speech act performance: theoretical, empirical and methodological issues. Amsterdam: John Benjamins, 26, 237-256.

[48] Vásquez, C. \& Sharpless, D. (2009). The role of pragmatics in the master's TESOL curriculum: Findings from a nationwide survey. TESOL Quarterly 43.1, 5-28.

[49] Xiaoning, Z. (2017). Politeness strategies in requests and refusals. In Z. Xiaoning, Politeness strategies in requests and refusals by Chinese college EFL learners. Master thesis, Nanjing University.

[50] Zaferanie, E., \& Hosseini-Maasoum, S. M. (2015). Pragmatic representations in Iranian high school English textbooks. The Journal of Applied Linguistics 8.16, 187-198.

[51] Žegarac, V., \& Pennington, M. C. (2008). pragmatic transfer. In H. Spencer-Oatey, Culturally speaking: Culture, communication and politeness theory ( $2^{\text {nd }}$ ed.). Great Britain: Continuum, 141-163.

Marzieh Saadatmandi is a master's students of TEFL at ELT department of higher education at Islamic Azad University, Karaj Branch, Iran. Her main field of interest is the incorporation of technology in second/foreign language teaching, pragmatics, and young learners' education.

Shahram Modarres Khiabani is Assistant Professor of department of English Language Translation at Islamic Azad University, Karaj Branch, Iran. He has published many articles and books mostly in morphology, corpus linguistics, and semantics. He has received his Ph.D. degree in General Linguistics.

Natasha Pourdana is Assistant Professor of ELT department of higher education at Islamic Azad University, Karaj Branch, Iran. She has published several books and research articles mainly in language teaching, language assessment, and EFL teacher education teaching and learning. She got her Ph.D. in Applied Linguistics (TEFL/TESL). 